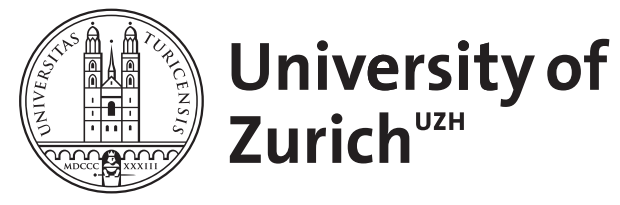

Zurich Open Repository and Archive

University of Zurich

University Library

Strickhofstrasse 39

CH-8057 Zurich

www.zora.uzh.ch

Year: 2011

Reforming European financial supervision: adapting EU institutions to market structures

Alexander, Kern

DOI: https://doi.org/10.1007/s12027-011-0216-x

Posted at the Zurich Open Repository and Archive, University of Zurich ZORA URL: https://doi.org/10.5167/uzh-71485

Journal Article

Originally published at:

Alexander, Kern (2011). Reforming European financial supervision: adapting EU institutions to market structures. ERA Forum, 12(2):229-252.

DOI: https://doi.org/10.1007/s12027-011-0216-x 


\title{
Reforming European financial supervision: adapting EU institutions to market structures
}

\section{Kern Alexander}

Published online: 11 June 2011

(C) ERA 2011

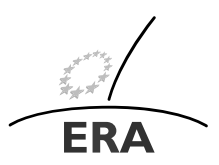

EUROPÄISCHE RECHTSAKADEMIE ACADEMY OF EUROPEAN LAW ACADEMIE DE DROIT EUROPEEN ACCADEMIA DI DIRITTO EUROPEO TRIER - TREVES - TREVIRI

\begin{abstract}
EU policymakers have created a new European System of Financial Supervision, consisting of three European Supervisory Authorities and a European Systemic Risk Board. This article examines some of the legal and institutional issues, including the ESAs' authority to develop an EU code of financial regulation and to oversee its implementation by Member States and resolve related disputes. The article argues that the creation of the ESAs and ESRB is a proportional response to the increased integration of EU financial markets and the cross-border nature of systemic risk. The article suggests, however, that the ultimate effectiveness of these supervisory reforms will depend on whether they achieve a balance between crisis prevention supervisory measures and crisis management involving the rescue or resolution of financial firms. A better balance needs to be struck to achieve financial stability objectives.
\end{abstract}

Keywords Regulated Industries and Administrative Law · Financial Institutions and Services · EU Law · Government Policy and Regulation · Law and Economics: General

\section{Introduction}

The growing integration of European financial markets and the financial crisis that began in 2007 have raised important questions concerning the institutional design of

This paper is based on a contribution given by the author at the ERA conference on The reform of EU financial supervision, held in Brussels on 9-10 December 2010.

Professor K. Alexander ( $₫)$

Faculty of Law, University of Zurich, Rämistr. 74/22, 8001 Zurich, Switzerland

e-mail: s.k.alexander@qmul.ac.uk 
European financial supervision. ${ }^{1}$ Over 50 large financial institutions have significant cross-border operations in EU states, while wholesale capital markets are increasingly inter-connected across EU states through electronic exchanges and trading platforms, clearing houses and the over-the-counter (OTC) derivatives market. Over the last 10 years, EU financial legislation has grown dramatically in its scope of application to many areas of market activity. ${ }^{2}$ The implementation and enforcement of this legislation has been left ultimately to the discretion and authority of Member State supervisors based on the principle of home country control and mutual recognition. Although the home country control regime facilitated trade and investment in financial services across EU states, the adoption of the euro and the institutional consolidation of the Lamfalussy process led to calls for further consolidation of supervisory practices at the EU level. Moreover, the recent financial crisis demonstrated major weaknesses in the EU supervisory framework and the need to have a robust macro-prudential supervisory regime across the EU that reinforces micro-prudential supervision by Member States.

To address these weaknesses, the European Commission proposed four Regulations ${ }^{3}$ in September 2009 that aimed to restructure substantially EU financial supervision, thereby creating a new European System of Financial Supervision (ESFS), consisting of a European Systemic Risk Board (ESRB) to monitor macro-prudential risks and three EU supervisory authorities (ESAs) whose functions include adopting a harmonised EU regulatory code and technical guidance standards for implementing EU financial legislation, and overseeing Member States' supervisory practices. ${ }^{4}$ The ESA's main functions involve coordinating the micro-prudential supervision of Member States and resolving any disputes between Member States or between Mem-

\footnotetext{
${ }^{1}$ See Report of the High-Level Group on Financial Supervision in the EU, chaired by Jacque De Larosière (Brussels, 25 Feb. 2009) (hereinafter 'Larosière Report'); Mulbert and Wilhelm [9] and Wymeesrch [13].

${ }^{2}$ Tridimas [10].

${ }^{3}$ European Commission, Proposal for a Regulation on Community macro prudential oversight of the financial system and establishing a European Systemic Risk Board COM(2009) 499; European Commission, Proposal for a Regulation establishing a European Banking Authority COM(2009) 501; European Commission, Proposal for a Regulation establishing a European Insurance and Occupational Pensions Authority COM(2009) 502; European Commission, Proposal for a Regulation establishing a European Securities and Markets Authority COM(2009) 503. See also European Commission Press Release, issued 23-9-2009.

${ }^{4}$ The Regulation creating the European Systemic Risk Board (ESRB) was approved by Council and Parliament on 24 November 2010. See Regulation No. 1092/2010 on European Union macro-prudential oversight of the financial system and establishing a European Systemic Risk Board, O.J. 2010 L331/1. The ESRB's operations became effective on 16 December 2010. See Regulation No. 1093/2010 establishing a European Supervisory Authority (European Banking Authority), O.J. 2010 L331/12; Regulation No. 1094/2010 establishing a European Supervisory Authority (European Insurance and Occupational Pension Authority), O.J. 2010 L331/48; Regulation No. 1095/2010 establishing a European Supervisory Authority (European Securities and Markets Authority), O.J. 2010 L331/84. See also Directive 2010/78/EU amending Directives 98/26/EC, 2003/6/EC, 2003/41/EC, 2003/71/EC, 2004/39/EC, 2004/109/EC, 2005/60/EC, 2006/48/EC, 2006/49/EC and 2009/65/EC in respect of the powers of the European Supervisory Authority (European Banking Authority), the European Supervisory Authority (European Insurance and Occupational Pensions Authority) and the European Supervisory Authority (European Securities and Markets Authority), O.J. 2010, L331/120. The three regulations creating the European Supervisory Authorities were approved by Council and Parliament in December 2010. See also Council Regulation No. 1096/2010 of 17 November 2010 conferring specific tasks upon the European Central Bank concerning the functioning of the European Systemic Risk Board, O.J. 2010 L331/162.
} 
ber States and the ESAs over the implementation and interpretation of EU legislation, while the ESRB will perform macro-prudential oversight and surveillance of systemic risk in EU and global financial markets and will have the authority to issue legally non-binding recommendations and warnings to Member States regarding their supervisory practices. The creation of the ESAs and ESRB builds on the Lamfalussy 3 Level 3 Committee framework which was essentially based on home country supervision with limited coordination between Member State supervisors. The new regime also has important implications for international supervisory and regulatory arrangements because the ESAs and the ESRB are likely to play a significant role in influencing the international regulatory agenda.

The overarching philosophical rationale for designing the European System of Financial Supervision is to control systemic risk within the internal market and to ensure that EU financial legislation is implemented by Member States in a harmonised way that complies with internal market objectives, such as providing a level playing field for financial firms and investors operating throughout the EU. The financial crisis demonstrates that systemic risk creates negative externalities in financial markets which have cross-border effects within the Union and that it is a necessary policy objective of the EU institutions to control financial risks that can threaten the efficient operations of the internal market. This article examines some of the legal and institutional issues regarding the creation of the ESAs and the ESRB and how the crossborder nature of systemic risk justifies a more consolidated institutional model of EU financial supervision. The article suggests that the constitutionality of the ESFS must be understood within the context of the need to establish the EU authorities to monitor and control systemic risk in EU (and globalised) financial markets. In examining the new regulatory and supervisory framework, the article analyses some of the main legal and economic policy issues concerning the institutional design of supervision and whether the new regime provides an adequate institutional and legal framework for EU financial supervision. The analysis will also address some of the advantages and disadvantages of other models, including the proposal for a single EU supervisor.

\section{The crisis and European financial integration}

The causes of the recent crisis have been attributed to macroeconomic factors, major weaknesses in corporate governance in financial institutions, and serious regulatory failings. ${ }^{5}$ The costs of the crisis for EU Member States have been enormous. In the UK, the cost of the crisis in terms of lost output and lower economic growth has been estimated at more than 19 per cent of UK GDP. ${ }^{6}$ It is evident that poorly regulated financial markets can lead to huge social costs for the broader economy and that these social costs in regional and globalised markets can be exported to other economies. Indeed, although there are economic benefits to membership of the EU's internal market in terms of greater access to cross-border financial services and capital flows,

\footnotetext{
${ }^{5}$ See Alexander et al. [2].

${ }^{6}$ See House of Commons Treasury Committee (2009), Opinion of proposals for European financial supervision. Press release (23-11-2009), p. 116.
} 
there are also social costs or externalities that arise from excessive financial risktaking and weak regulatory and supervisory regimes. For example, the collapse of the Royal Bank of Scotland and Fortis in 2008 demonstrates how the excessive risktaking of a Member State bank can generate cross-border externalities to other EU countries and financial systems. It is essential therefore that Europe have a more comprehensive framework for supervising and controlling the "negative externalities" of cross-border financial risk-taking. These externalities can be transmitted more easily throughout EU financial markets because of the greater degree of financial integration that has resulted in recent years from the liberalisation of the Union's internal financial market. ${ }^{7}$

A vast literature has emerged documenting the growing integration of European financial markets. ${ }^{8}$ Following adoption of the euro, there has been significant convergence in interest rate differentials in the wholesale banking and inter-bank markets. Although retail financial markets remain mostly fragmented, the cost of capital for equity and debt issuance has experienced a significant degree of convergence across EU states, while the composition of asset classes in most regulated investment funds has become less home-biased towards the domestic market. Nevertheless, the impact of the crisis led to a reversal of cross border bank lending and investment flows. ${ }^{9}$

The impact of the financial crisis on financial integration, however, has not been the same throughout the EU. The market segments that had experienced the highest degree of integration over the last decade were heavily impacted by the crisis, and in many cases saw a sharp reversal in the integration trend. For example, this was the case for the unsecured money markets, government bond markets and equity markets. ${ }^{10}$ It is not evident, however, whether these recent trends can be interpreted as a symptom of increasing long-term market segmentation or if they are linked to a temporary entrenchment by market actors within domestic borders. ${ }^{11}$

Nevertheless, EU financial markets have evolved to more integrated structures primarily because of liberalisation of capital restrictions and increased cross-border trade in banking services. This has been facilitated by the growing importance of the euro as a reserve currency and advances in technology that enable market participants to operate more easily in a cross-border environment. The challenge arising from the increasing integration of European and global financial markets and the recurrence

\footnotetext{
${ }^{7}$ See Alexander, Dhumale, Eatwell [1], pp. 120-125.

${ }^{8}$ European Central Bank, Financial Integration in Europe (April 2010) (Frankfurt: ECB); The European Commission, Report on EU Financial Integration (2009) (Brussels: Commission).

${ }^{9}$ European Central Bank, EU Banking Structures (Sept. 2010), pp. 21-22. The ECB noted that post crisis '[f]oreign branches lost market share to domestic institutions, and there was a pronounced decline in crossborder M\&As as banks shifted their focus from pursuing growth opportunities to repairing their balance sheets.' Ibid. p. 22.

${ }^{10}$ The European Commission, European Financial Integration Report 2009, Commission Staff Working Document (Brussels: 11 Dec. 2009), SEC(2009) 1702 final. Although EU states had experienced wider dispersions in the cost of capital since the crisis, these dispersions vary significantly from state to state. Ibid, p. 4.

${ }^{11}$ This interpretation seems to be supported by the reversal of the trend of some indicators (i.e. in the interbank lending market and in the government bond markets) in the latter part of 2008 and beginning of 2009. However, further information and time are needed to clearly decode these developments. See Commission $(2009,17)$.
} 
of financial crises, such as the crisis that began in 2007, is how to strike the right institutional balance between EU institutions and Member States in the regulation and supervision of financial markets. ${ }^{12}$

\section{EU financial legislation and institutional developments}

EC financial services directives have traditionally adopted a functionalist approach to financial regulation by requiring the same type of activity to be subject to the same regulatory rules, even though the activity may be performed by different types of financial institutions (e.g. universal bank or investment bank). ${ }^{13}$ Moreover, EC legislation does not require Member States to adopt a particular institutional structure of financial regulation. ${ }^{14}$ States may use a single regulator for prudential supervision (i.e. German Bafin) or divide those responsibilities between two bodies, usually a central bank for prudential regulation and a capital market regulator for conduct of business (so-called "twin peaks" approach, as in the Netherlands), or a three-pillar institutional model (banking, insurance and securities) along sectoral lines. In some systems, the central bank plays an important role in overall prudential supervision and in regulating the clearing and settlement system (Italy), while in other countries a single regulator or supervisor exercises these functions (Sweden).

Financial supervision in the EU was conducted essentially by the Member State authority where the financial firm was incorporated or had its headquarters. Supervision was based on the principle of home country control in which the supervisor of the jurisdiction where the bank is chartered or incorporated exercised regulatory responsibility over the bank's cross-border EU operations. ${ }^{15}$ However, when an EUbased banking group had subsidiaries operating in other EU states, the supervision

\footnotetext{
${ }^{12}$ The Larosière Report recognises the difference between 'regulation' and 'supervision' by defining '[r]egulation as a set of rules and standards that govern financial institutions' which 'can take many different forms', whereas 'supervision is the process designed to oversee financial institutions in order to ensure that rules and standards are properly applied.' See the High Level Group on Financial Supervision in the EU' (chaired by Jacques de Larosière), Report, (Brussels, 25 Feb. 2009). See also Wymeersch [12], pp. 237-306 (TM Asser Institut) (stating that "regulation" refers essentially to rule-making, while "supervision" involves applying the rules and judgement to a specific case).

${ }^{13}$ See First Council Directive 77/780/EEC of 12 December 1977 on the coordination of the laws, regulations and administrative provisions relating to the taking up and pursuit of the business of credit institutions, O.J. L 322, (17/12/1977), pp. 30-37, Art. 1; Second Council Directive 89/646/EEC of 15 December 1989 on the coordination of the laws, regulations and administrative provisions relating to the taking up and pursuit of the business of credit institutions and amending Directive 77/780/EEC, O.J. L 386, (30.12.1989), pp. 1-3, Art. 1 (6).

${ }^{14}$ However, this has changed somewhat in the securities area, as EU states are now required to establish a single enforcement authority to enforce the Market Abuse Directive and a single listing authority for all issuers to file prospectuses under the Prospectus Directive.

${ }^{15}$ Since the 1980s, EU legislation applied the principle of home country control to the cross-border operation of banks and other financial institutions, which holds that regulatory authority over banks that conduct activities through their branches in other member "countries" lies with the competent authorities in the EU/EEA state where the institution's head office is incorporated: see Council Directive 89/299/EEC of the European Parliament and Council of April 17, 1989, OJ 1989 L 124, p. 16; and Council Directive 89/646/EEC of the European Parliament and Council of December 15, 1989 (OJ 1989 L 386, p. 1); Directive 2000/12/EC of the European Parliament and Council of March 20, 2000 relating to the taking up
} 
of those subsidiaries was exercised by the host state supervisor of the jurisdictions where the subsidiaries were incorporated. The regulatory policy incentives of home country regulators were primarily to protect depositors and creditors of banks based in their home jurisdictions. This institutional model worked well as long as banking activities were largely confined to one country-normally the country where the bank was incorporated and had its home license. ${ }^{16}$ It also worked well for banking groups which had fragmented management structures in which the management of foreign subsidiaries was largely autonomous from the day-today management of the parent group, hence allowing the foreign subsidiaries' management to deal independently with host state supervisors. As global financial markets, however, have become more inter-connected, the structure of banking markets and their management have changed significantly. Large banking groups have been created from a growing number of cross-border bank mergers. As a result, many banking groups today have major operations in multiple jurisdictions where they can pose systemic risk to a host state banking system.

Moreover, large banks are increasingly dependent on international capital markets for much of their funding. Banking groups are also progressively centralising a number of key functions at the group level. For instance, risk management, liquidity management, funding operations and credit control, are typically exercised at the group level or in specialised affiliates in order to gain economies of scale and synergies in specialist operations. This also has led to the distinction between branches and subsidiaries becoming blurred. ${ }^{17}$

It was argued prior to the 2007 crisis that developments in EU market structures and firm operations, including risk management, posed serious difficulties for the EU's home country supervisory system on the grounds that home country authorities lacked the institutional and legal capacity to oversee adequately the cross-border risk-taking of EU banking and financial institutions. As a result, EU financial markets were more exposed to harmful risk taking in other jurisdictions and that financial crises were more difficult for Member State authorities to control and contain. Nevertheless, the EU regulatory and supervisory framework of home country control

and pursuit of the business of credit institutions, OJ 20000 L 126, p. 1. See also Peter Paul and others $v$ Bundesrepublik Deutschland, judgement of the Court of Justice of the European Communities, Case C222/02, 12 October 2004 (recognising that Member State national authorities had a number of supervisory obligations pursuant to EU law vis-à-vis credit institutions and the exercise of those obligations throughout the Community based on the principle of home country control).

${ }^{16}$ But see Caixa-Bank France v Ministere de l' Economie, des Finances et de l' Industrie, judgement of the Court of Justice of the European Communities, C-442/02, October 5, 2004 (invalidating a French legislative prohibition on the payment of interest for "sight" accounts for a French subsidiary of a holding company based in another EU state because it constituted an unnecessary restriction on freedom of establishment for the holding company, though the French government justified its prohibition on the grounds of consumer protection and promoting medium and long-term savings). The effective application of the home country principle based on minimum standards and mutual recognition is premised on the pursuit of common regulatory objectives and trust between regulatory authorities.

${ }^{17}$ For instance, it is unlikely that policymakers would allow a large subsidiary bank operating in one jurisdiction to stay in business if its parent company bank defaults or fails in another jurisdiction (at least not for the short-run). 
based on mutual recognition and minimum harmonisation of standards accomplished a great deal in promoting the objectives of the European internal market. ${ }^{18}$

\subsection{The Lamfalussy institutional model}

The EU Financial Services Action Plan (1999) and the Lamfalussy Committee Report (2000) recognised how the changing structures of EU financial markets made it necessary for Europe to have a more harmonised legal and regulatory regime govern capital markets and the prudential supervision of financial institutions. Indeed, regarding financial supervision, the Lamfalussy four-level process for devising and implementing EU financial legislation and regulation was considered an important institutional step that would allow the EU to achieve greater financial market integration which would lead to greater economic growth. ${ }^{19}$ The 3 Level 3 Lamfalussy committees - the Committee of European Banking Supervisors (CEBS), the Committee of European Securities Regulators (CESR), and the Committee of European Insurance and Occupational Supervisors (CEIOPS) - were successful prior to the crisis in expediting the regulatory standard-setting process by making it more flexible and efficient. ${ }^{20}$ The successful operation of the Level 3 networks depended on cooperation and frequent contacts between Member State supervisors. Although they were successful to some extent, it became evident that the changing structure of EU financial markets necessitated further institutional coordination in the Level 3 committees to address the growing inter-connectedness of wholesale capital markets and the cross-border activities of large financial groups.

From a constitutional perspective, it is important to note that the Lamfalussy programme did not create a legislative competence in the Level 3 committees to supervise financial markets, nor did it enhance the Commission's legal authority in this area. Indeed, the original Report of the Committee of Wise Men (the Lamfalussy

\footnotetext{
${ }^{18}$ According to minimum harmonisation, Member States are required to harmonise what are considered to be the essential areas of banking regulation while being free to surpass these essential minimum standards and to maintain higher distinctive regulatory practices in areas not harmonised so long as they are pursuing valid public policy objectives and do not unnecessarily infringe on EC Treaty Freedoms.

${ }^{19}$ The four levels consisted of: (1) legislative proposals of high level principles through the traditional EU co-decision process; (2) based on the legislative proposals, EU finance ministers agree to implementing measures for Member States; (3) Member State regulators make proposals to Level 2 Finance Ministers regarding the implementing measures and then consult with each other regarding implementation; and (4) national compliance and enforcement (see Lamfalussy Committee, The Final Report of the Committee of Wise Men on the Regulation of European Securities Markets (Brussels: 15 Feb. 15, 2001). The Lamfalussy process applied to all major financial sectors, including banking, securities, insurance and pension fund management.

${ }^{20}$ The three so-called Lamfalussy Level 3 networks consisted of the Committee of European Securities Regulators (CESR), the Committee of European Banking Supervisors (CEBS), and the Committee of European Insurance and Occupational Pensions Supervisors (CEIOPS). Commission Decision 2001/527/EC (6 Jan. 2001) (establishing Committee of European Securities Regulators); Commission Decision 2004/5/EC (5 Nov. 2003) (establishing Committee of European Banking Supervisors); and Commission Decision 2004/6EC (establishing Committee of European Insurance and Operational Pensions Supervisors (CEIOPs)). Initially applying only to the decision-making of EU securities regulators, the Lamfalussy process was extended in 2004 to the banking, insurance and occupational pension sectors as well.
} 
Report) in 2000 envisioned only two principal functions for the Level 3 committees: (1) technical advice regarding the development of implementing measures, and (2) promotion of consistent implementation of Community legislation and enhancement of convergence in EU supervisory practices. It was intended essentially to be a regulatory process that relied on comitology procedures (Arts. 290 and 291 TFEU, ex-Arts. 202 and 211) to develop EU financial legislation based on proposals from national finance ministers and regulators, in consultation with industry. The early stages of implementation of the Lamfalussy programme raised some concerns regarding the scope of authority of the Commission to adopt binding rules for the Member States regarding their implementation of EU financial legislation. It became clear however that the Commission would rely on the Member States acting within the Level 3 committees to negotiate and coordinate the implementation of EU legislation in a legally non-binding way which allowed Member States full discretion to adopt regulatory rules (not prescribed in legislation) and supervisory practices according to national administrative rules. Nevertheless, Level 3 Committee decision-making played an important role in setting the regulatory agenda and enhancing cooperation between Member States, while facilitating a wide ranging dialogue with industry and consumer groups, and disseminating its work and proposals to relevant stakeholders. The Council and Parliament recognised the early success of the Lamfalussy process and the ongoing work of the 3 Level 3 committees in coordinating the supervisory activities of Member State authorities. The Lamfalussy framework was, however, criticised as being too slow and lacking the institutional capacity to respond effectively to a cross-border financial crisis within the European Union. ${ }^{21}$

Prior to the crisis, EU authorities had recognised that the growing integration of wholesale capital markets and the cross-border operations of large banking groups raised important questions about the effectiveness of the Lamfalussy framework in performing effective supervision of European financial markets. ${ }^{22}$ Moreover, the International Monetary Fund's surveillance reports identified the weak link in EU supervisory arrangements to be the absence of a clear framework of coordination between EU national supervisors with respect to the oversight of the cross-border operations of financial groups in EU states. ${ }^{23}$ The recognised weaknesses of the Lamfalussy institutional framework became even more apparent in 2007 and 2008 when the credit crisis incapacitated wholesale financial markets and the Lehman Brothers collapse demonstrated the incapacity of EU Member State authorities to manage and contain a crisis with extensive cross-border effects.

In response, the De Larosière Committee Report concluded that it was necessary to have more effective cross-border oversight of financial risk-taking and that Member State authorities lacked the institutional capacity and legal powers to ensure that EU

\footnotetext{
${ }^{21}$ Alexander et al. [2], pp. 31-33.

${ }^{22}$ See CEBS and the European System of Central Bank's Banking Supervisory Committee (BSC) Joint Guidance (2006) (extending the guidance role of the Level 3 committees from "going-concern" activities to crisis management cooperation).

${ }^{23}$ See IMF article IV Surveillance Report (2007), p. 27, and see also IMF article IV Surveillance Report (2006) para. 12.
} 
financial services legislation was being faithfully implemented and that member authorities were exercising adequate prudential supervision. ${ }^{24}$ Not only should microprudential supervision be reinforced, but it was also necessary for the EU to develop a more effective macro-prudential oversight system. ${ }^{25}$ The De Larosière Committee therefore proposed the creation of a European System of Financial Supervision, consisting of 3 new EU supervisory authorities in the areas of banking, securities and insurance, respectively, and a European Systemic Risk Committee (the forerunner to the ESRB). The 3 ESAs would coordinate the supervisory practices of Member State authorities to ensure effective micro-prudential supervision, while the ESRC would be responsible for exercising macro-prudential oversight and monitoring systemic risk in the EU financial system. The Committee's proposals were welcomed by the Commission and constituted the key elements of the Commission's proposed regulations in September 2009 for a European System of Financial Supervision.

The subsidiary and proportionality principles underpin the creation of the ESFS, which provide that in areas where EU Institutions and member states do not have exclusive competence, the creation of EU supervisory authorities can only be legally justified on the following grounds: that the objectives of financial regulation and supervision cannot be satisfactorily met at the national level, and that the creation of a EU supervisory authority is proportional and necessary to coordinate member states efforts to control and mitigate systemic risk. Indeed, EU financial markets are characterised by substantial cross-border externalities. The crisis demonstrated how the home country control system had come under strain because of the growing cross-border operations of a large number of EU-based financial institutions and the growing inter-connections in the wholesale capital markets (e.g. structured finance) and between small and medium sized firms. Indeed, the credit crisis that began in 2007 demonstrated the cross-border nature of systemic risk in global as well as in EU financial markets; this was evident through counterparty exposures in the money markets and disruptions to the cross-border operations of many large banking groups and financial conglomerates. These changes in EU financial markets had made the traditional home country control regime and the Lamfalussy framework obsolete in performing effective supervision over the changing European financial marketplace. It is submitted therefore that the cross-border nature of systemic risk necessitates the creation of the ESAs to promote the harmonised implementation of EU financial legislation and regulation, and to ensure that Member States coordinate and harmonise their supervisory practices.

\subsubsection{The need for macro-prudential supervision}

A major weakness in most EU Member States' prudential regulation was that supervisory practices were focused primarily on individual financial firms and investors, while not taking into account broader macro-economic factors, such as aggregate levels of risk in the financial system or how risk was being shifted to non-bank firms and investors in the broader capital markets. Supervisory practices were focused narrowly

\footnotetext{
${ }^{24}$ The 'De Larosière Report', above n. 12, pp. 26-27.

${ }^{25}$ Ibid., pp. 39-41, 57.
} 
on individual firms, while neglecting structural developments in capital markets and in clearing and settlement systems. For instance, the EU states whose regulatory and supervisory practices had contributed the most to the propagation of the crisis had adopted market sensitive regulatory standards which had incorporated the flawed risk management models used by banks and other financial firms to measure and manage risk. These risk management models excessively relied on historic data from the bank's balance sheet to measure the risk facing individual institutions, while failing to take account of macro-level or system-wide shocks that could affect the whole financial system. Most banks' risk management models did not take into account the level of risk that had been shifted to off-balance sheet entities, nor did they incorporate the risks related to the growing leverage on banks' balance sheets. These regulatory weaknesses were especially acute with the UK Financial Services Authority whose supervisory approach was largely micro-prudential; it focused primarily on whether or not individual firms themselves were managing their risk appropriately, and not on the effect of the individual firms' risk-taking on the financial system as a whole. ${ }^{26}$ This regulatory approach however failed to take into account the fallacy of composition that what appears for individual firms to be rational and prudent actions in managing their own risk exposures under individual circumstances can, if followed by all firms, potentially produce imprudent or excessively risky outcomes for the whole financial system. ${ }^{27}$

Macro-prudential regulation will change regulation for individual banks in two main areas: (1) the regulation of individual firms must take into account both firm level practices and broader macro-economic developments in determining how regulatory requirements will be applied to firm risk-taking (i.e. linking the growth of asset prices and GDP with contra-cyclical bank reserves and liquidity ratios), and (2) limitations on the type of financial products and investments offered because of controls on the overall levels of risk-taking and leverage at the level of the financial system (i.e. limits on loan-to-value and loan-to-income ratios). Implementing macro-prudential regulation will require that micro-prudential regulation become more rules-based because tighter ex ante constraints will be needed for the risk exposures of individual firms (i.e. leverage ratios and limits on maturity mismatches in wholesale funding) ${ }^{28}$ Prudential regulation will gradually become more rules-based in order to achieve macro-prudential objectives. Macro-prudential regulation will change the nature of prudential regulation because the supervisory focus will be expanded to include the

\footnotetext{
${ }^{26}$ The Turner Review: A regulatory response to the global banking crisis (March 2009, London, The Financial Services Authority). In the case of the UK, excessive reliance on principles-based regulation (PBR) also exacerbated weaknesses in the UK supervisory framework. The PBR approach focused on incentivising individual firm to experiment with different risk management practices so long as they achieved satisfactory firm outcomes that were measured by firm performance (i.e. shareholder prices) and whether the FSA's 11 high level principles were being achieved (i.e. treating customers fairly). The FSA's PBR approach did not take into account the aggregate effect of firms' performance on the financial system in terms of leverage generated and liquidity risks from wholesale funding exposures. To address adequately these macro-prudential risks in the future, prudential regulation will necessarily become more rules-based at the level of the firm and at the level of the financial system.

${ }^{27}$ See Brunnemeier [5], pp. 17-20 (discussing fallacy of composition).

${ }^{28}$ See discussion in House of Lords Select Committee on Economic Affairs (June 2009) "Banking Supervision and Regulation," Volumes 1 \& 2 (London: House of Lords).
} 
application of macro-prudential controls to the broader financial system. Naturally, this will create new incentives for market participants to avoid the requirements by adopting new financial instruments and structures which may lead to new regulatory risks. Supervisors and central banks should be vigilant therefore as to how the market may respond to new macro-prudential controls.

The new focus on macro-prudential supervision will require supervisors to engage in surveillance of the financial system by monitoring aggregate leverage in the markets, the inter-connectedness between firms (large and small) in wholesale funding markets, and the impact of monetary policy on financial markets. Supervisors will also have to take into account macro-prudential factors in deciding how to apply micro-prudential controls on individual firms. Any consideration of a future model of EU supervision must take into account the links between micro-prudential regulation of individual firms and macro-prudential oversight of the financial system.

\section{The European system of financial supervision}

The creation of the European System of Financial Supervision consisting of the ESAs and the ESRB provides significant institutional consolidation of financial supervision at the EU level in order to conduct more effectively macro-prudential oversight and micro-prudential supervision and regulation. In doing so, EU policymakers have decided to accept in principle the institutional framework proposed by the Larosière Committee to consolidate supervision along the lines of the pre-existing 3 Level 3 committees of the Lamfalussy framework. The newly created ESAs have legal personality and competence to adopt a harmonised regulatory rulebook and technical

Table 1 European System of Financial Supervision

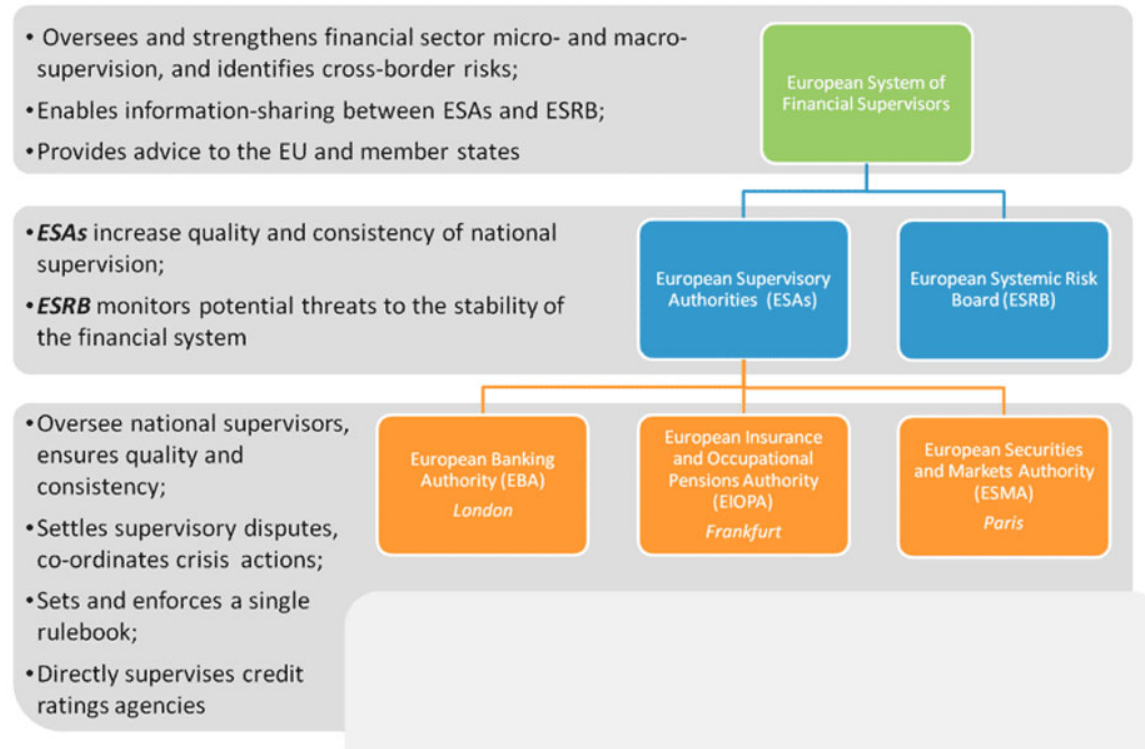

Source: UK Treasury (2011) 
guidance standards for Member State supervisors and the authority to ensure consistent application of EU financial legislation and regulatory rules. The creation of the ESRB aims to complement the work of the ESAs by enhancing EU Member States' capacity to assess and monitor systemic risks and perform macro-prudential oversight of European and global financial markets. Examples of macro-prudential oversight would include obtaining data from supervisors on large systemically important financial institutions and on the transmission of risk in interconnected wholesale financial markets.

\subsection{European Systemic Risk Board (ESRB)}

The ESRB consists of a General Board, a Steering Committee, a Secretariat, an Advisory Technical Committee, and an Advisory Scientific Committee. ${ }^{29}$

The ESRB was established to be the main body responsible for macro-prudential oversight and surveillance of EU financial markets. ESRB Regulation, Article 3 (1) states:

\section{"The ESRB shall be responsible for the macro-prudential oversight of the finan- cial system within the Community in order to prevent or mitigate systemic risks within the financial system, so as to avoid episodes of widespread financial dis- tress, contribute to a smooth functioning of the Internal Market and ensure a sustainable contribution of the financial sector to economic growth."}

Despite its lack of formal institutional structure, it has a broad remit to exercise a number of important functions in the field of macro-prudential oversight, including monitoring sources of systemic risk and other risks to financial stability across EU countries and financial sectors and serving as an institutional voice for EU central bankers in shaping and developing macro-prudential supervisory practices. It also will interact with global financial stability bodies to develop effective early warning systems. The ESRB will aim to identify and prioritise the risks and use stress testing and other methodologies to analyse how they can impact financial stability.

The ESRB became operational on 16 December 2010 and consists of 65 representatives and officials consisting of the EU central bank governors, representatives of the European Supervisory Authorites, the Economic and Finance Committee, and the European Commission, all serving on a General Board. The first chairperson of the ESRB is the ECB President who will hold office for a five year term. ${ }^{30}$ The ESRB will have two Vice Chairs: the first Vice Chair will be elected by and from the ESRB board members who are also members of the ECB General Council (i.e. eurozone central bank governors), while the second Vice Chair is the Chair of the Joint Committee of the ESAs. ${ }^{31}$ The legal basis of the Regulation is Article 114 TFEU. ${ }^{32}$ The

\footnotetext{
${ }^{29}$ ESRB Regulation, Art. 4. For a more detailed discussion of the ESRB institutional structure, see Ferran and Alexander [7].

${ }^{30}$ ESRB Regulation, Art. 5(1).

${ }^{31}$ ESRB Regulation, Art. 5(3).

${ }^{32}$ Art. 114 TFEU, OJ C 115/47 (9/5/2008), ex Art. 95 TEC, which allows 'measures for the approximation of the provisions laid down by law, regulation or administrative action in Member States which have as their object the establishment and functioning of the internal market'.
} 
ESRB monitors and assess systemic risks arising from individual banks and across the whole European financial system. In doing so, it seeks to draw connections between macroeconomic conditions and structural developments in financial markets, and identify vulnerabilities with particular institutions.

The ESRB would also issue recommendations and warnings to countries or financial groups or other concerned entities and would report all recommendations and warnings to the Council of Ministers and to the European Parliament. The ESRB would devise specific follow-up procedures and "moral incentives" to follow its recommendations and if supervisors decide not to follow the recommendations they are obliged to explain why not. The ESRB can inform the Council if unsatisfied with a Member State or entity's explanation and can conduct "name and shame" publicity if necessary. The ESRB will be assisted by a steering committee that will assist it in decision-making, reviewing and preparing for meetings of the General Board, and monitoring the ESRB's work progress. The steering committee membership will be the Chair and First Vice-Chair of the ESRB, and four other members of the ESRB General Board elected for three year terms by and from the General Board's members who are also members of the ECB General Council (i.e. eurozone central bank governors). ${ }^{33}$

The Regulation confers a specific role for the European Central Bank in the ESRB's operation: the ECB provides the secretariat for the ESRB while performing administrative, logistical and analytical support. This would also include drawing on technical advice from the 27 EU national central banks and supervisors. ${ }^{34}$ However, the ECB's integral role in providing administrative support, and overseeing and discharging the operations of the ESRB, is constrained by Article 127 (6) TFEU that requires a unanimous vote by the Council to allow the ECB to carry out any function for the ESRB that directly involves the prudential supervision of financial institutions. So the extent and scope of the ECB's Secretariat role may be limited to functions not involving micro-prudential supervision of individual financial institutions, but permitting macro-prudential oversight.

The ESRB is expected to provide a broader perspective of the financial system and to interact with supervisors in monitoring and assessing system-wide risks. In this capacity, the ESRB would serve as the basis for developing a more integrated EU supervisory structure that would improve consistency in regulatory and supervisory practices and approaches across EU/EEA states, thus creating a level playing field and a more efficient regulatory framework for controlling cross-border systemic risk and preventing market failure.

The capacity of the ESRB to perform its function of identifying and monitoring systemic risk has been called into question because there is inadequate understanding of the causes of systemic risk and that the proposed ESRB Regulation does not

\footnotetext{
${ }^{33}$ The steering committee also includes a European Commission member, the Chairs of each of the ESAs, the President of the Economic and Finance Committee, the Chair of the Advisory Scientific Committee, and the Chair of the Advisory Technical Committee. See ESRB Regulation, Art. 11.

${ }^{34}$ See speech of Jose Manuel Gonzalez-Paramo, Member of the Executive Board of the ECB, January 22 (2010), p. 4.
} 
provide any information on what systemic risk means and how to measure it. ${ }^{35}$ Moreover, the design of the ESRB has been criticised as being flawed. In addressing this concern, it is submitted that although systemic risk is difficult to measure, and its causes are even more difficult to identify precisely (especially for a future financial crisis), EU policymakers should not conclude therefore that they should not try to establish institutional frameworks to monitor systemic risks across EU financial markets. Indeed, the financial crisis demonstrates that macro-prudential risks are evident in the European financial system. ${ }^{36}$ For example, banks have exposure to each other throughout Europe in the money markets through a variety of risk exposures, and European policymaking needs to have better surveillance of the cross-sectoral systemic risks posed by certain banking groups and financial conglomerates that operate in Europe.

The crisis also demonstrates that systemic risk arises in the wholesale capital markets-especially through the securitisation and the over-the-counter credit default swap markets - as well as from individual financial institutions. The Turner Review recognised that the sources of systemic risk can be macro-prudential in nature and that this necessitates that central banks and regulators establish enhanced cross-border (international and European) frameworks for identifying and monitoring macro-prudential systemic risks and, in certain circumstances, for issuing early warnings to affected countries. The absence of a consensus view on the sources of systemic risk therefore does not preclude the design of effective cross-border institutional structures to monitor and measure systemic risks in European financial markets.

Other critics raised the concern that the composition of the ESRB was too heavily weighted in favour of central bankers and observed that a ESRB dominated by EU central bankers should not be given such an important role because over the last decade "the ECB, the Eurosystem NCBs, and the rest of the national NCBs [had] not exactly covered themselves with glory in the area of macro-prudential supervision and regulation." 37 Also, because all decisions to bail out a bank or provide other crisis assistance requires approval of national fiscal authorities, it has been argued that EU Finance Ministries should also be represented on the ESRB. Nevertheless, the ESRB's absence of legal personality provides it with more institutional flexibility and scope to fulfil its core functions and a broad mandate to monitor the whole European financial system. It also allows the ESRB to interact flexibly with the ESAs and Member State supervisors to form a common framework of regulation that allows for regulatory innovation to address evolving market risks.

\footnotetext{
${ }^{35}$ See oral evidence of Jon Danielsson, The Committee's Opinion on proposals for European financial supervision, House of Commons Treasury Committee (Sixteenth Report of session 2008-09), Ev 1.

${ }^{36}$ Alexander et al. [2], pp. 2-3, 17-18.

${ }^{37}$ See "The Committee's Opinion on proposals for European financial supervision", House of Commons Treasury Committee (Sixteenth Report of session 2008-09), p. 18 (citing the written evidence by Willem Buiter). Indeed, the ECB Financial Stability Review stated in June 2007 just before the credit crisis that ' $[w]$ ith the Euro area financial system in a generally healthy condition and the economic outlook remaining favourable, the most likely prospect is that financial system stability will be maintained in the period ahead.' ECB Financial Stability Review [6], p. 9.
} 


\subsection{The European Supervisory Authorities (ESAs)}

The ESFS would consist of a network of Member State supervisors that would operate within three different ESAs with responsibility for banking, insurance and securities markets, respectively. ${ }^{38}$ Each Member State supervisor would continue to be responsible for discharging its supervisory functions, but under the ESA regulations it would have to account for its supervisory practices to the relevant ESA. Each ESA will be responsible for adopting a harmonised rule-book, technical standards and guidance for the application and implementation of EU financial legislation. As discussed below, their most important immediate responsibility would be to formalise the operations of the colleges of supervisors which presently oversee the cross-border operations of Europe's largest 50 or so banks and financial institutions. The decision to build the ESFS along sectoral lines-banking, securities and insurance-was influenced significantly by the existing sectoral approach of the Lamfalussy framework. EU policy makers could have diverged away from the Lamfalussy sectoral approach by proposing instead to create a single EU financial supervisor for all financial services, or alternatively a single EU supervisor for each of the three financial sectors. Rather, the Commission chose to build directly on the existing framework by transforming the 3 Level 3 supervisory committees into more formalised institutional structures with legal personality and the power to resolve disputes between supervisors and to issue Directives enjoining supervisors to bring their practices into compliance with EU law and regulatory codes. This path-dependent approach recognised that the transaction costs-both institutional and political—would have been much higher if EU policymakers had proposed a more dramatic institutional shift away from the Lamfalussy framework. Also, equally important, the use of the Lamfalussy institutions on which to build the ESFS recognised that a new formalised EU institutional structure was nevertheless to be firmly and primarily anchored in Member State competence to supervise financial markets. The ESFS/ESA framework builds on the existing decentralised Member State supervisory approach by enhancing the ability of supervisors to coordinate cross-border oversight along with enhanced accountability to other Member States to ensure faithful implementation of EU law.

Moreover, the ESA institutional framework recognises the interdependence between micro- and macro-prudential risks across EU financial markets and the need to be accountable to the views of market participants and all EU stakeholders, including financial institutions, investors and consumers. It provides a more consolidated and rational institutional design for linking micro-prudential supervision of individual firms with the supervision of the linkages between institutions and between institutions and the broader financial system.

\subsection{The ESFS and colleges of supervisors}

The ESFS would place greater emphasis on using colleges of supervisors from EEA states to supervise the operations of Europe's largest cross-border banks and financial institutions. The European Banking Authority has responsibility for overseeing

\footnotetext{
${ }^{38}$ Regulation of the European Parliament and of the Council COM(2009) 503 (establishing a European Securities and Markets Authority), COM(2009) 502 (establishing a European Insurance and Occupational Pensions Authority), and COM(2009) 501 (establishing a European Banking Authority).
} 
the implementation of guidelines and decision-making procedures for the colleges. Membership of the colleges would include: All EEA supervisors of subsidiaries; EEA supervisors of branches recognised as significant; third country supervisors with equivalent confidentiality provisions; and central banks as appropriate. Moreover, the Capital Requirements Directive (CRD) (Art 131a) provides the legal basis for a single college for global EEA-based banks. The main function of colleges will be to exchange information between supervisors, coordinate communication between supervisors of the financial group, voluntary sharing and/or delegation of tasks, joint decision on model validation (e.g. Basel II). The colleges will also be involved in joint risk assessment and joint decision on the adequacy of risk-based capital requirements. The planning and coordination of supervisory activities for the financial group and in preparation of and during emergency situations (i.e. crisis management). The ESAs will have oversight of the colleges and will have authority through conciliation and mediation to resolve disputes between member authorities in the colleges. Some concern has been expressed that this power of conciliation and mediation might infringe Member State fiscal autonomy, but the better view holds that these concerns are exaggerated as the ESAs will only be able to resolve disputes and devise rules and technical standards for national supervisors based on the requirements of EU financial legislation.

\subsection{The fiscal autonomy of Member States}

The Regulations establishing the ESFS provide no authority for EU institutions to order Member States to spend taxpayer funds in a crisis (i.e. bail out a bank). Indeed, ESA Regulations do not provide a crisis management mechanism that would require a member authority to use public funds in a crisis. In other words, the sovereignty of Member States with respect to their fiscal prerogative to support ailing financial institutions has not been intruded upon. In fact, the fiscal safeguards provision of article 38 of the EBA Regulation does not permit the EBA to take any measures under articles 18 or 19 that would require a Member State to make fiscal expenditures. The fiscal safeguards provision applies to the authority of the ESAs to resolve disputes between member supervisors under article 19.

Some Member State Parliaments, however, have expressed concern that the fiscal safeguard provisions of article 38 only apply to orders issued by an ESA under articles 18 and 19, and that an ESA could potentially order a member authority under some other article of the Regulations to take action that might involve fiscal expenditure. ${ }^{39}$ This possibility was pointed out with respect to the original draft article 21 of the EBA Regulation which authorised the ESAs to order a member authority to comply with a recommendation or warning issued by the ESRB. Council addressed these concerns by amending the ESA regulations with article 36 to make it clear that no ESRB recommendation or warning could be made legally binding by the ESA on a member state authority.

\footnotetext{
${ }^{39}$ House of Commons Treasury Committee, "The Committee's Opinion on proposals for European financial supervision", House of Commons Treasury Committee (Sixteenth Report of session 2008-09, London: House of Commons).
} 


\subsection{Delegation of regulatory powers to the ESAs and ESRB}

Another area of possible legal challenge concerns the Commission's use of Article 114 (ex art 95) of the Treaty as the legal basis to adopt the regulations creating the ESAs and the ESRB. Article 114 (ex art 95) authorises EU institutions to create EU agencies and other EU bodies with delegated powers to facilitate the harmonised implementation of EU law. ${ }^{40}$ The ECJ has interpreted Article 114 to require that the legislation creating such bodies demonstrate that it is actually and objectively apparent from the legal act creating the body that its purpose is to improve the conditions for the establishment and functioning of the internal market. ${ }^{41}$ Moreover, the ECJ has observed that the responsibilities delegated to such a body be closely linked to the subject matter of the relevant harmonising legislation. ${ }^{42}$ However, the scope of authority to be delegated under Article 114 to EU agencies/bodies is limited by the so-called Meroni doctrine that holds that EU agencies cannot be delegated ultra vires powers (that is, powers that are not already conferred by Treaty on EU institutions) to implement EU law. ${ }^{43}$ Moreover, ECJ jurisprudence also prohibits EU institutions from delegating intra vires powers to EU agencies or bodies if such powers delegate substantial discretion to EU agencies to make decisions that essentially involve policymaking; for example, decisions involving the allocation of economic resources between competing interests. Such discretionary policymaking can only be taken by EU institutions based on their conferred Treaty-based powers. EU agencies and bodies are therefore limited to drafting and proposing regulatory rules and technical standards that do not imply strategic decisions or policy choices and whose content is limited by the EU legislation on which they are based.

The ESAs are authorised to perform what are essentially agency functions under EU law, that is, to make decisions involving the drafting of regulatory technical standards, adopting non-binding recommendations and guidelines, and facilitating member authorities' implementation of a common EU regulatory code which is approved

\footnotetext{
${ }^{40}$ The EU institutions (Parliament and Council) are permitted to use Article 114 as the legal basis for establishing EU bodies that are vested with responsibilities for contributing to the harmonisation process and facilitating uniform implementation of EU legislation by Member States. United Kingdom v European Parliament (Smoker Flavourings) (C-66/04) [2005] E.C.R. I-10553; [2006] 3 C.M.L.R. 1. See also, United Kingdom v European Parliament (ENISA) (C-217/04) [2006] E.C.R. I-3771; 3 C.M.L.R. 2.

ENISA (C-217/04) [2006] E.C.R. I-3771 at [45] (stating 'where the Community body thus established provides services to national bodies and/or operators which affect the homogenous implementation of harmonising instruments which are likely to facilitate their application').

${ }^{41}$ Smoke Flavourings (C-66/04) [2005] E.C.R. I-10553 at [45] (stating "the expression 'measures for the approximation' in Article 95 EC" [art 114 TFEU] 'was intended to confer on the Community legislature a discretion, depending on the general context and specific circumstances of the matter to be harmonised, as regards the harmonisation technique most appropriate for achieving the desired result, in particular in fields which are characterised by complex technical features.' See also ENISA (C-217/04) [2006] E.C.R. I-3771 at [43]. See discussion in Borchadt and Wellens [4], pp. 297-298.

${ }^{42}$ ENISA (C-217/04) [2006] E.C.R. I-3771 at [45] (stating 'that the tasks conferred on such a body must be closely linked to the subject matter of the acts approximating the law, regulations and administrative provisions of the Member States').

${ }^{43}$ Meroni \& Co., Industrie Metallurgiche, SPA v High Authority of the European Coal and Steel Community, (C-9/56) [1958] E.C.R. I-00133.
} 
by Commission, Parliament and Council. ${ }^{44}$ Under the Regulations, the Commission has a delegated power to review and approve ESA proposed draft regulatory technical standards (Article 10(1)) and implementing technical standards (Article 15 (1)). The regulatory technical standards and implementing technical standards constitute, in part, a harmonised rulebook to ensure consistency of supervisory practice amongst Member States, and to mediate and resolve disputes between Member States and between Member States and the ESAs. The ESAs exercise considerable influence because of the financial market expertise of their staff, stakeholder groups, and supervisory representatives of member states. Moreover, they exercise considerable discretionary authority to develop legally nonbinding guidelines and recommendations (Article 8 (1)(a)) that contribute to the content of regulatory and supervisory standards, and they can impose orders with Commission approval on member state authorities or financial institutions requiring them to comply with EU financial legislation listed in Article 1(2).

As mentioned above, the ESAs and the ESRB were established by Regulation under Article 114 TFEU. The ESAs were established as bodies with legal personality and possessing delegated binding powers, whilst the ESRB was established as a body without legal personality and no direct legally binding powers. ${ }^{45}$ Despite these differences, it is submitted that the delegation of powers issues that are raised under Article 114 TFEU are very similar for these bodies and the same general EU institutional issues are raised by the exercise of their functions. Any challenge on Treaty grounds, however, against the ESFS and ESAs will have difficulty prevailing for the important reason that the newly-established EU supervisory framework remains essentially decentralised in its operations because it relies primarily on the exercise of financial supervision by Member State authorities in areas of micro-prudential and macro-prudential supervision, despite the obligation of member authorities to coordinate their supervisory practices with each other and to provide supervisory information to the EU central banks through the ESRB. It is submitted therefore that the Regulations establishing the ESFS, ESAs and the ESRB would likely withstand constitutional challenge because they maintain the essential decentralised supervisory structure with Member States exercising ultimate competence to supervise financial markets while building lines of accountability to other EU states through the European supervisory agencies.

The ESAs and the ESRB were established by Regulation under article 114 TFEU. The ESAs were established as bodies with legal personality with binding power to issue decisions that are approved by the Commission, while the ESRB was established as a body without legal personality and with no binding powers. ${ }^{46}$ The ESRB Regulation emphasises the advantages of flexibility that flow from the absence of legal personality. ${ }^{47}$ It suggests that this will allow the ESRB, together with the ESFS, to "form a common innovative framework for financial supervision, while maintaining a

\footnotetext{
${ }^{44}$ European Commission, European Agencies-the Way Forward COM(2008) 135.

${ }^{45} \mathrm{COM}(2009)$ 499. Indeed, the ESRB Regulation emphasises the advantages of flexibility that flow from the absence of legal personality. Ibid, explanatory memorandum, para. 4 .

${ }^{46} \mathrm{COM}(2009) 499$.

${ }^{47}$ Ibid, explanatory memorandum, para 4.
} 
clear distinction of responsibilities between [itself] (...) and the other bodies." 48 The Commission also links the ESRB's lack of legal personality to the "wide scope and the sensitivity of its missions." 49 It appears, however, that this policy choice was also influenced by more pragmatic considerations because of certain technical difficulties pertaining to the ECB's capacity to provide services to another legally-constituted body. ${ }^{50}$

Some commentators argue that the lack of legal personality and binding powers need not necessarily be an impediment to the ESRB establishing authority and influence in relation to the financial markets. It may be compared in this respect to the Financial Stability Board, which is also a body without legal personality. ${ }^{51}$ It is the quality of what the ESRB does rather than its organisational form that will determine its external impact. ${ }^{52}$ The ESRB's lack of legal personality, however, could hamper the ESRB in maintaining an appropriate distance from the ECB. ${ }^{53}$ However, the ECB while exercising its administrative support function will also probably be concerned to ensure a proper demarcation so that its role in relation to the ESRB does not interfere with the performance of its monetary policy and price stability tasks.

Regarding the ESAs, the preamble of their Regulations state that their objective is to "contribute directly to achieving the objectives of the internal market." 54 Yet mere assertion of an internal market role does not guarantee that the legislative measures in question (in this case, the Regulations creating the ESAs) are intra vires. In determining whether the ESA regulations comply with the Treaty's delegation of powers principles, it is thus necessary to examine the ESA's mission and the specific tasks conferred on it. Essentially, the ESAs would provide a point of contact for national supervisors to interact and coordinate their oversight of cross-border financial firms and address matters of mutual concern between Member State supervisors and the ESAs. Moreover, the ESAs would perform specifically delegated tasks, such as mediating disputes between supervisors and, if necessary, resolving disputes.

It is important to observe that these tasks would not involve the delegation of discretionary powers that would require a margin of political judgement. The EU institutions cannot delegate powers to EU agencies to make generally binding rules, but rather can only delegate limited powers to make decisions on narrow technical matters. ${ }^{55}$ The alleged inflexibility of EU law with respect to delegation is questioned in the academic literature but this interpretation has been accepted by the Commission. The Commission also takes the view that there are further restrictions on the decision-making agencies' scope for action and will authorise them to intervene only

\footnotetext{
${ }^{48}$ Ibid.

${ }^{49}$ Ibid, para 6.

${ }^{50} \mathrm{C}$ Zilioli, 'The EU September Package of Reform: A View from the EU Institutions' (conference presentation, London, 11 December 2009).

${ }^{51}$ See Declaration of London (2 April 2009), para 8 (reconstituting the Financial Stability Forum into the Financial Stability Board as a soft law international body).

${ }^{52} \operatorname{COM}(2009) 499$, para 6.1.

${ }^{53}$ Ferran, Alexander [7].

${ }^{54}$ EC Regulation preamble, nineteenth recital.

${ }^{55}$ See generally Lenaerts [8].
} 
in areas where a single public interest predominates and in areas where the agencies are not called upon to arbitrate on conflicting public interests, exercise any powers of political appraisal or conduct any complex economic assessments. ${ }^{56}$

\section{Some related considerations}

\subsection{What role for a single EU supervisor?}

There remains an important objection to the Regulations creating the ESFS and ESRB on public policy grounds that they do not go far enough. ${ }^{57}$ In the aftermath of the crisis, there have been proposals to establish a single EU supervisor for the largest 50 or so financial institutions with cross-border operations throughout Europe. ${ }^{58}$ Their significant regional, and indeed global, scope makes them amenable to a transnational supervisory structure that is consolidated at the European level in the form of a single EU prudential supervisor that would have full competence to supervise these firms and their foreign branches and subsidiaries. The main argument for institutional consolidation at the EU level is that Europe's growing internal financial market is much more integrated-both at the level of the financial system and at the level of firms operating cross-border-which cannot be supervised efficiently by Member States acting independently because of different institutional capacities and supervisory practices. It is argued that a centralised EU supervisory body would have a number of advantages that include promoting a level playing field in supervisory practices, coordinating and overseeing the activities of Member State authorities, and conducting cross-border surveillance and enforcement. ${ }^{59}$ Similarly, a single EU supervisor could also play an important role in supervising the growing inter-connected infrastructure of EU capital markets, in particular the clearing houses and certain settlements systems that operate at EU level. An important rationale for this is that national supervisors have high transactions costs in supervising the cross-border dimension of financial markets and a single EU supervisor can reduce these transaction costs by coordinating the activities of member authorities. The rationale for this is not only that it would be extremely difficult for national supervisors to obtain a clear picture of these institutions and their operations, but even more because their potentially risky operations may create significant cross-border externalities, which makes supervising them solely by one national supervisor suffer from a serious incentive

\footnotetext{
${ }^{56}$ See European Commission, The operating framework for the European Regulatory Agencies $\operatorname{COM}(2002) 7189$.

${ }^{57}$ European Shadow Financial Regulatory Committee (November 2009) "A new Life for European Financial Supervision," Statement No. 31 (Stockholm).

${ }^{58}$ Considerable support has emerged for a single EU financial supervisor across all financial sectors or a single supervisor along the lines of each of the main financial services sectors-banking, securities and insurance. See Andenas, Avgerinos [3] (suggesting a single EU banking regulator as an ideal model in light of the crisis).

${ }^{59}$ The creation of an EU supervisor could potentially reduce the high transaction costs of monitoring and enforcing EU law on a cross-border basis. Further, a single supervisor could assist with resources and training for some member authorities in need of assistance.
} 
problem. Further consolidation of EU supervision, however, would not be permitted by the Treaty. The Treaty for European Union crystallises this institutional limitation. But some argue that politicians should address this absence of Treaty authority for creating a single EU supervisor by amending the Treaty to allow this to be done (ESFRC 2009).

Although there are recognised benefits to such a centralised institutional structure, there are some concerns regarding the sovereignty costs that states would incur by allowing such an authority to have jurisdiction to monitor and enforce EU law in their jurisdictions. An extensive literature has emerged questioning the utility and effectiveness of the single supervisory model for Europe. ${ }^{60}$ Moreover, on constitutional grounds, there are critics who assert that the Commission and EU bodies do not have a conferred power to engage in prudential supervision or even macroprudential surveillance. ${ }^{61}$ According to this view, the Meroni doctrine ${ }^{62}$ would prohibit the Commission and Council from creating an EU agency and then delegating powers to the agency to supervise EU financial markets on the grounds that prudential supervision has not been conferred by the Treaty on EU institutions and therefore cannot be delegated to a newly created EU supervisor.

Based on these objections, it was more legally realistic for the Commission to have set forth proposals on supervisory consolidation that approximate those proposed by the Larosière Committee. Indeed, the Commission's proposals were welcomed in many quarters precisely because any further institutional consolidation beyond that proposed by the Larosisere Committee would have been on weaker constitutional grounds insofar as article 114 TFEU was serving as the legal basis for creating EU supervisory authorities who are deemed necessary to promote the harmonised implementation of EU financial legislation.

\subsection{What about supervisory oversight for the ESCB/ECB?}

Other advocates of more centralised EU supervision suggest that the European Central Bank or the European System of Central Banks (ESCB) has a role to play in performing macro-prudential oversight and supervision. ${ }^{63}$ As a general matter, the ECB is responsible for overseeing the smooth operation of the eurozone payment system, but it is legally prohibited under Article 127 (6) TFEU from engaging in prudential supervision of individual financial institutions unless it obtains unanimous consent from EU states. ${ }^{64}$ Macro-prudential supervision, however, involves oversight and the assessment of risks across the financial system, and not simply prudential supervision

\footnotetext{
${ }^{60}$ Vives [11], pp. $57-82$.

${ }^{61}$ See House of Commons Treasury Committee Final Report (23 Nov. 2009).

${ }^{62}$ Case 9/56 Meroni v High Authority [1957-1958] ECR 133.

${ }^{63}$ Gonzalez-Paramo, Jose Manuel (January 22, 2010), Speech, Presentation of the Report, Member of the Executive Board of the ECB (Madrid).

${ }^{64}$ The ECB's main tasks involve macro-prudential oversight including the oversight of the payment and settlement system, price stability assessments and monetary policy. In performing these functions, however, the ECB is prohibited expressly from engaging directly in prudential supervision under Article 127 (6) of the Treaty on the Functioning of the European Union (TFEU). Nevertheless it has responsibility to "contribute to the smooth conduct of policies pursued by the competent authorities relating to the
} 
of individual financial institutions. Moreover, a strong argument can be made that the ECB and/or the ESCB should be allowed to conduct oversight of clearing and settlement systems (including the operations of central counterparties operating in the EU) because of the language provided in the fourth indent of Article 127 (2) TFEU and Articles 3.1 of the Statute of the European System of Central Banks and of the European Central Bank that provides in relevant part that ' $[\mathrm{t}]$ he ECB and national central banks may provide facilities, and the ECB may make regulations, to ensure the efficient and sound clearing and payment systems within the Community and with other countries. ${ }^{65}$ Further, Article 22 of the ESCB Statute provides additional authority for the ECB to adopt regulations to ensure the efficiency and soundness of EU clearing, settlement and payment systems within the Union and between the Union and other countries. ${ }^{66}$

The ESCB/ECB's treaty powers in this area may clash with the Commission's proposed Regulation on Market Infrastructure (EMIR) that would provide sole authority to the European Securities and Markets Authority (ESMA) to supervise the EU clearing and settlement system, including supervision of clearing houses, derivatives and other financial instruments subject to a clearing requirement. ${ }^{67}$ In response, the ECB argued in a legal opinion in January 2011 that the ESCB's responsibility for the smooth operation of payment systems and 'to implement the monetary policy of the Union' in Article 127 (2) indent 1 (also provided in Article 3.3 of the Statute of the ESCB) depends on its ability to promote the smooth operation of clearing and settlement systems and infrastructures and therefore is a basic task of the Eurosystem. ${ }^{68}$ Accordingly, the ECB argues that EMIR should be amended to recognise expressly the ESCB's role in overseeing EU clearing systems and that it should be made clear that it has joint authority with ESMA to provide oversight and supervision in this area. ${ }^{69}$

prudential supervision of credit institutions and the stability of the financial system" (Art 127 (5) TFEU). How might the ECB "contribute to the smooth conduct of policies" in the Eurosystem and throughout the EU without having access to supervisory information? An examination of the EU legal framework applicable to the exchange of information between central banks and supervisory authorities suggests that the EU regime is "asymmetric" because although the ECB and European System of Central Banks are obliged to contribute to the smooth functioning of supervisory policies, supervisory authorities do not have an equivalent responsibility to contribute to the tasks of the ECB or ESCB. Until this asymmetry is rectified, the EU will fail to have effective macro-prudential supervision. One of the tasks of the ESRB is to facilitate a balance flow of information between supervisors and central banks in order to establish effective macro-prudential oversight of the EU financial system.

${ }^{65}$ Art 127 (2) (TFEU) - fourth indent. The ECB adopted an opinion on 13 January 2011 that the Commission proposed Regulation on Market Infrastructure (EMIR) should be amended so that the European system of Central Banks would be given oversight responsibility for the operation of EU central counterparties and any third party central counterparty operating in EU markets. The legal authority cited for this proposal was Article 127 (6) that provides that one of the basic tasks to be carried out through the ESCB is the promotion of the smooth operation of the payment system.

${ }^{66}$ Article 22 of the ESCB Statute. See discussion in Alexander et al. (2006), p. 122 and p. 282.

${ }^{67}$ See Commission proposal for a Regulation on Market Infrastructure (22 Sept. 2010).

${ }^{68}$ See ECB Opinion of 13 January 2011 (Con/2011/1) p. 2.

${ }^{69}$ The ECB also observes national central banks whose currency is not the euro would also have similar powers to oversee clearing and related infrastructure as the ECB would have in acting through the National Central Banks of the Eurosystem. 
On the other hand, the ESCB's oversight authority over clearing may lead central banks and in particular the ECB operating through the Eurosystem to engage in supervisory oversight of individual CCPs, which are in many EU states authorised credit institutions, which are prohibited from being subject to direct 'prudential supervision' under article 127, by the ECB unless there is unanimous consent by the Council of Ministers. ${ }^{70}$ This raises important issues regarding the scope of the ESCB's oversight of the EU clearing system and whether its oversight of the clearing and payment systems overlaps with Member States' prudential supervision of CCPs. Generally, however, it would appear that the ESCB would have a strong claim as a legal matter to be involved in the oversight of the clearing system. ${ }^{71}$

\section{Conclusion}

The recent crisis demonstrates how systemic risk in liberalised financial markets creates significant risks for supervisors and policymakers in seeking to protect their economic and financial systems from the fallout of financial failure. European financial markets are increasingly integrated in terms of cross-border operations of institutions and wholesale capital markets and system infrastructure. Prior to and during the crisis, EU financial supervision had failed to link micro-prudential supervision with macro-prudential oversight of the financial system. Based on these regulatory and supervisory weaknesses, the De Larosière Report (2009) supported the creation of an EU macro-prudential regulatory regime that directly links the micro-prudential supervision of individual firms and persons with the macro-prudential oversight of the EU and global financial system. The creation of the ESFS/ESAs and ESRB has dramatically consolidated institutional oversight of EU financial markets at the EU level.

The Regulations, however, though institutionally complex, essentially maintain Member State competence to supervise financial markets, but require supervisors to coordinate their actions with respect to cross-border firms and incorporate systemic risk concerns into their supervisory practices. The ESAs and ESRB appear to provide a robust institutional framework for macro-prudential supervision that is durably linked to Member State micro-prudential supervision. However, simply creating new EU institutions is not enough. EU policy makers should also be concerned with the substantive requirements of financial legislation and whether or not they contribute to moral hazard in financial markets by creating incentives for market participants to engage in excessive and socially costly risk-taking. Another important area that should be given more recognition in supervisory strategies is that crisis prevention-through

\footnotetext{
${ }^{70}$ Art 127 (6) TFEU provides in relevant part: 'the Council may, acting unanimously on a proposal from the Commission and after consulting the ECB and after receiving the assent of the European Parliament, confer upon the ECB specific tasks concerning policies relating to the prudential supervision of credit institutions.'

${ }^{71}$ Accordingly, the Commission may want to consider appropriate amendments to EMIR to recognise the ESCB's role in this area.
} 
prudential supervision — and crisis management — mitigating a crisis by resolutionare part of a seamless process. This means effective prudential supervision also requires effective crisis management mechanisms, which include resolution procedures for banks and other systemically important firms, policies regarding too big to fail banks, and deposit insurance. Indeed, the ESAs are not authorised to engage in crisis management and would have no authority to use public funds to resolve bank failures or some other systemic problem involving a financial institution. Therefore, their ultimate effectiveness can be called into question. Is it really realistic to create EU bodies with ex ante responsibilities for micro and macro supervision while not having the authority to bail out, nationalise, or unwind a large bank or to engage in other financial rescues? The link between crisis prevention and crisis management therefore should be high on the EU policy agenda and without a better balance between the two at the EU level the new Regulations creating the ESFS will fail to achieve their overall objective of controlling systemic risk.

\section{References}

1. Alexander, K., Dhumale, R., Eatwell, J.: Global governance of financial systems: the international regulation of systemic risk (2006)

2. Alexander, K., et al.: Financial supervision and crisis management in the EU (2007)

3. Andenas, M., Avgerinos, Y.: Financial Markets in Europe, London (2003)

4. Borchadt, G., Wellens, K.: Soft law in European community law. Eur. Law Rev. (1989)

5. Brunnemeier, M., Goodhart, C.A.E., Persaud, A., Shin, H.: The fundamental principles of financial regulation (2008)

6. European Central Bank: Financial Stability Review (June 2007) (Frankfurt: ECB)

7. Ferran, E., Alexander, K.: Can soft law bodies be effective? Soft systemic risk oversight bodies and the special case of the European systemic risk board. Working paper (2010). http://papers.ssrn.com/ sol3/papers.cfm?abstract_id=1676140

8. Lenaerts, K.: Regulating the regulatory process: delegation of powers in the European community. Eur. Law Rev. 23 (1993)

9. Mulbert, P., Wilhelm, A.: Reform of EU banking and securities regulation after the financial crisis. Bank. Finance Law Rev., 188-231

10. Tridimas, T.: EU financial regulation: federalisation, crisis management and law reform. In: Craig, P., de Burca, G. (eds.) The Evolution of EU Law, 2nd edn. (2011)

11. Vives, X.: Restructuring financial regulation in European Monetary Union. J. Financ. Serv. Res. (2001)

12. Wymeersch, E.: The structure of financial supervision in Europe: about single financial supervisors, Twin Peaks and multiple financial supervisors. Eur. Bus. Organ. Law Rev. 8(2), 237-306 (2009)

13. Wymeersch, E.: The reforms of the European financial supervisory system-an overview. Eur. Co. Financ. Law Rev. 7(2), 240-265 (2010) 